Dicle Tıp Dergisi / Dicle Med J (2019) 46 (3) : 443 - 448

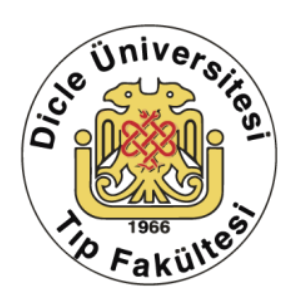

WWW.diclemedj.org

Original Article / Özgün Araştırma

\title{
Comparison of the Bethesda system classification and postoperative cytology of thyroid nodules: A single center experience
}

\author{
Yasar Ozdenkaya', Cenk Ersavas², Oktay Olmuscelik³, Pelin Basim4, Irem Ozover5, \\ Mehmet Seker6, Naciye Cigdem Arslan ${ }^{7}$
}

1 Department of General Surgery, Istanbul Medipol University Medical Faculty Istanbul, Turkey ORCID: 0000-0003-0428-2511 2 Department of General Surgery, Istanbul Medipol University Medical Faculty Istanbul, Turkey ORCID: 0000-0001-5134-1014

3 Department of Internal Medicine, Istanbul Medipol University Medical Faculty Istanbul, Turkey ORCID: 0000-0002-9815-1848

4 Department of General Surgery, Istanbul Medipol University Medical Faculty Istanbul, Turkey ORCID: 0000-0002-9452-9276

5 Department of Pathology, Istanbul Medipol University Medical Faculty Istanbul, Turkey ORCID: 0000-0001-7525-3732

6 Department of Radiology, Istanbul Medipol University Medical Faculty Istanbul, Turkey ORCID: 0000-0002-6745-0159

7 Department of General Surgery, Istanbul Medipol University Medical Faculty Istanbul, Turkey ORCID: 0000-0002-2282-7207

Received: 26.02.2019; Revised: 17.06.2019; Accepted: 25.06.2019

\begin{abstract}
Objective: Recent American Thyroid Association Guideline emphasizes that identifying the institutional malignancy risks for each Bethesda category is mandatory to achieve more accurate preoperative diagnosis in thyroid nodules. Aim of this study is to compare the preoperative fine needle aspiration biopsy (FNAB) and postoperative pathology results in a single institution in the era of the Bethesda System for Reporting thyroid Cytology (TBSRTC).

Methods: The data of the patients who underwent FNAB and thyroidectomy between 2012 and 2018 were collected retrospectively. Patients who had available TBSRTC classification were included in the study. The malignancy risk of each TBSRTC classification was calculated.

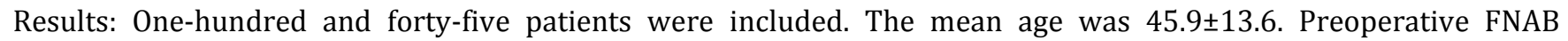
categorization was TBSRTC I in 3 (2.1\%) patients, TBSRTC II in 47 (32.4\%) patients, TBSRTC III 16 (11\%) patients, TBSRTC IV in $14(9.7 \%)$ patients, TBSRTC V in 29 (20\%) and VI in $36(24.8 \%)$ patients. Postoperative pathology revealed malignancy in 66 (45.5\%) of the patients. The malignancy risk was 33.3\% in TBSRTC I, $4.3 \%$ in TBSRTC II, $31.3 \%$ in TBSRTC III, $42.9 \%$ in TBSRTC IV, $62.1 \%$ in TBSRTC V and $94.4 \%$ in TBSRTC VI categories.

Conclusion: Our results were conformable with the malignancy risks reported by TBSRTC. Larger studies should be performed to validate and endorse nationwide standardization of the Bethesda system.
\end{abstract}

Keywords: Goiter, Bethesda classification, fine needle aspiration biopsy, papillary thyroid carcinoma, thyroid nodule.

DOI: 10.5798/dicletip.620391

Yazışma Adresi / Correspondence: Naciye Cigdem Arslan, MedipolEsenler Hospital, Department of Surgery, Birlik mah. Bahceler cd. No:5, Esenler, Istanbul, Turkey e-mail: cigdemarslan@hotmail.it 


\section{Tiroid nodüllerinde Bethesda sınıflandırması ve postoperatif patolojinin karşılaştırılması: Tek merkez sonuçları}

\section{Öz}

Amaç: Güncel Amerikan Tiroid Derneği kılavuzu Bethesda sınıflandırmasında merkeze özel sonuçların bilinmesinin tiroid ince iğne aspirasyon biyopsisinin (İ̈AB) tanısal yeterliliğini artırmak için önemli olduğunu vurgulamaktadır. Bu çalışma Bethesda sınıflandırması ve postoperatif patoloji sonuçlarını kıyaslayarak her kategori için merkezimize özel kanser riskini ortaya konulmasını amaçlamaktadır.

Yöntemler: Merkezimizde 2012-2018 yılları arasında tiroid nodülü nedeniyle ameliyat edilen hastaların ameliyat öncesi ve sonrası patoloji sonuçları geriye yönelik olarak incelendi. Bethesda sistemine göre sınıflandırılmış İ̇AB raporları olan hastalar çalıșmaya dahil edildi. Ameliyat sonrası patolojiler incelenerek Bethesda sisteminin her kategorisi için ayrı ayrı kanser riskleri ortaya konuldu ve literatürle kıyaslandı.

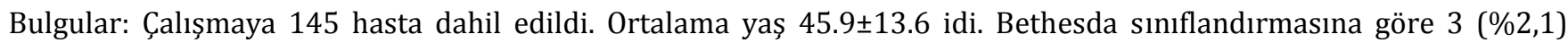
hasta kategori I, $47(\% 32,4)$ hasta kategori II, $16(\% 11)$ hasta kategori III, $14(\% 9,7)$ hasta kategori IV, $29(\% 20)$ hasta kategori V ve $36(\% 24,8)$ hasta kategori VI olarak raporlanmıştı. Ameliyat sonrası patoloji $66(\% 45,5)$ hastada malignite ile uyumluydu. Malignite riski kategori I için \%33,3, kategori II için \%4,3, kategori III için \%31,3, kategori IV için \%42,9, kategori 5 için \%62,1 ve kategori VI için \%94,4 olarak hesaplandı.

Sonuç: Sonuçlarımız Bethesda sistemi tarafından bildirilen malignite riskleriyle uyumluydu. Bethesda sınıflandırmasının doğrulanması ve ulusal adaptasyonun artırılması için daha geniş çalışmalara gereksinim vardır.

Anahtar kelimeler: Guatr, total tiroidektomi, Bethesda sınıflandırması, ince iğne aspirasyon biyopsisi, tiroid nodülü.

\section{INTRODUCTION}

The prevalence of palpable thyroid nodules is approximately $5 \%$ of the population and raises up to $60 \%$ with ultrasonography ${ }^{1}$. Only $5-7 \%$ of those are malignant ${ }^{2}$. The main problem in the management is distinguishing benign and malign lesions. Ultrasonography and fineneedle aspiration biopsy (FNAB) are currently the most common diagnostic tools. Fine-needle aspiration biopsy is a minimally invasive, safe and cost-effective method with high sensitivity and specificity. Several studies have demonstrated a significant decrease in unnecessary thyroid surgery with the use of $\mathrm{FNAB}^{3}$, however false negative and false positive results are the main limitations, as well as the variety in interpretation and sampling technics.

In 2007, a standardized reporting system was introduced to overcome the confliction in cytological interpretation and terminology. The Bethesda System for Reporting Thyroid Cytology (TBSRTC) suggested 6 categories each representing a specific cancer $\mathrm{risk}^{4}$. This categorization has enabled to determine the malignancy risk of thyroid nodules and let the clinicians to assess the potential outcomes of surgery or follow-up. The "intermediate for malignancy" group was tiered into 3 subcategories with different described risk of cancer (Table 1). Moreover, a new cytological category, atypia of undetermined significance (AUS), was also introduced with TBSRTC. Those changes led a significant decrease in surgery rates when compared with the period before TBSRTC without any decrease in malignancy rates $^{5}$. The benefit of TBSRTC has been represented by several studies and metaanalyses $^{6-9}$. However, TBSRTC alone may fail in decision making particularly in intermediate (III, IV and V) categories and adjunct diagnostic methods such as repeating FNAB, molecular testing and lobectomy have been recommended for more accurate diagnosis ${ }^{10-11}$.

The American Thyroid Association (ATA) guidelines endorsed TBSRTC categorization, 
pointing out that the positive and negative predictive values of all diagnostic tools including TBSRTC are influenced by the institutional cancer rate in each cytological category ${ }^{11}$.In the most recent update, ATA concluded that it is crucial to know the prevalence of malignancy within each TBSRTC category, at one's own institution ${ }^{10}$. In this study we performed a comparitive analysis of FNAB and postoperative pathology results, which also presents the effect of TBSRTC categorization and our insitutional cancer risk in each cyologic category.

\section{METHOD}

Approval of local ethics committee was received for the study (No: 10840098604.01.01-E.53650). All the patients gave written consent for the surgery and permission for the use of data in studies. An institutional board-approved database of thyroidectomy was reviewed. The data of the patients who underwent FNAB and thyroidectomy between 2012 and 2018 were collected retrospectively. In our institution, TBSTRC has been used for rendering thyroid FNAB since 2012. Diagnostic terminology including 6 categories was applied; I: Non-diagnostic, II: Benign, III: AUS of follicular lesion of undetermined significance, IV: Follicular neoplasm or suspicious for follicular neoplasm, V: Suspicious for malignancy, VI: Malignant (Table 1). Patients who did not have available TBSRTC categorization or postoperative pathology were excluded from the study.

Table 1. The 2017 Bethesda System for Reporting Thyroid Cytopathology: Recommended diagnostic categories, implied risk of malignancy and recommended management ${ }^{10}$.

\begin{tabular}{lcl}
\hline Diagnostic category & Risk of malignancy (\%) & Recommended management \\
\hline I.Non-diagnostic or unsatisfactory & $5-10$ & Repeat FNAB with USG \\
\hline II.Benign & $0-3$ & Follow-up \\
\hline $\begin{array}{l}\text { III.Atypia of undetermined significance } \\
\text { Or Follicular lesion of undetermined significance }\end{array}$ & $10-30$ & $\begin{array}{l}\text { Repeat FNAB, molecular testing, } \\
\text { lobectomy }\end{array}$ \\
\hline $\begin{array}{l}\text { IV.Follicular neoplasm } \\
\text { Or suspicious for a follicular neoplasm }\end{array}$ & $25-40$ & Molecular testing, lobectomy \\
\hline V.Suspicious for malignancy & $50-75$ & Thyroidectomy \\
\hline VI.Malignant & $97-99$ & Thyroidectomy \\
\hline
\end{tabular}

FNAB: Fine -needle aspiration biopsy, USG: Ultrasonography

Current guidelines of ATA were followed in the management of the patients ${ }^{12}$. Thyroid FNABs were performed by radiologists under ultrasound guidance. The FNAB and thyroidectomy specimens were evaluated at institutional pathology laboratory. There was no on-site evaluation for adequacy of FNAB. All the thyroidectomies were performed by a single surgeon. The postoperative pathology reports were reviewed and malignancy rate for each TBSRTC category was recorded.

\section{Statistical Analysis}

The data were recorded to a SPSS for Windows V.21 database and descriptive analyses were performed. Continuous variables were expressed as means and standard deviation and categorical variables as frequency and percentages.

\section{RESULTS}

Between 2012 and 2018, 201 patients underwent thyroidectomy for thyroid nodules. Proper TBSRTC classification was not 
performed in 34 patients, the FNAB was performed in another institution in 16 patients and 6 patients did not agree to participate. Meeting inclusion criteria, 145 patients were

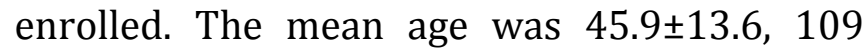
(74.7\%) patients were female and 37 (25.3\%) were male. Preoperative categorization was TBSRTC I in $3(2.1 \%)$ patients, TBSRTC II in 47
(32.4\%) patients, TBSRTC III 16 (11\%) patients, TBSRTC IV in $14(9.7 \%)$ patients, TBSRTC V in 29 (20\%) and VI in 36 (24.8\%) patients. Postoperative pathology revealed malignancy in $66(45.5 \%)$ of the patients. The details of FNAB and postoperative pathology and implied cancer risks can be seen in Table 2 .

Table 2. Preoperative diagnostic category, postoperative histology and risk of malignancy

\begin{tabular}{ccccc}
\hline \multirow{2}{*}{ Diagnostic category of TBSRTC } & \multirow{2}{*}{$(\%)$} & \multicolumn{2}{c}{ Postoperative pathology $(\mathrm{n})$} & \multirow{2}{*}{ Risk of malignancy (\%) } \\
\cline { 3 - 4 } & & Benign & Malign & \\
\hline I & $3(2.1 \%)$ & 2 & 1 & 33.3 \\
\hline II & $47(32.4 \%)$ & 45 & 2 & 4.3 \\
\hline III & $16(11 \%)$ & 11 & 5 & 31.3 \\
\hline IV & $14(9.7 \%)$ & 8 & 6 & 42.9 \\
\hline V & $29(20 \%)$ & 11 & 18 & 62.1 \\
\hline VI & $36(24.8 \%)$ & 2 & 34 & 94.4 \\
\hline
\end{tabular}

TBSRTC: The Bethesda System for Reporting Thyroid Cytology

\section{DISCUSSION}

Since the TBSRTC has been introduced, the interpretation of FNAB was standardized with defined risk of malignancy for each category. This consensus on diagnostic terminology and standardized communication among clinicians has increased the diagnostic accuracy of FNAB and decreased unnecessary surgery for benign nodules, however the management of the patients in TBSRTC III, IV and V categories has still been a challenge. During decision-making, the clinician should discuss potential benefits and risks of the surgery or follow-up with colleagues and the patient. Therefore, it is important to be aware of institutional differences, experience and limitations of FNAB interpretation. The recent ATA recommendations emphasize that the prevalence of malignancy for the Bethesda categories should be documented individually for the reporting institution ${ }^{11}$. In this study, we aimed to review our 6-year experience of
TBSRTC categorization of FNAB and institutional implied malignancy risks for each

category. Our results provide insight for more accurate management of future patients. The validation of Bethesda system with postoperative pathologies may contribute to nationwide use of TBSRTC.

In a study of from United States, results of 1382 patients who underwent FNAB in community hospitals were presented. Their malignancy risk for TBSRTC II, III, IV and V were 3\%, 6\%, $22 \%, 56 \%$ and $100 \%$ which were all falling within the ranges published before ${ }^{13}$. The malignancy risk of each TBSRTC category in our study was compatible when compared with previous reports, except for TBSRTC I. Despite repeated FNAB, we could not detect a papillary microcarcinoma in one patient in TBSRTC I category which corresponded to $33.3 \%$ of malignancy risk. The carcinoma was found in the dominant nodule measuring $3.5 \mathrm{~cm}$ which underwent FNAB two times. The rate of nondiagnostic (TBSRTC I) FNABs has been 
reported between $2-34 \%$ in the literature ${ }^{14}$. Ultrasound guidance and on-site evaluation of the specimen for adequacy was strongly recommended to decrease the percentage of unsatisfactory biopsies ${ }^{14}$. In our institution we routinely perform FNAB under ultrasound guidance, but on-site evaluation is not performed. Our non-diagnostic FNAB rate was 2.1\%, however comparing our results in TBSRTC I category and high malignancy risk of $33.3 \%$ was not fair enough due to small number of the patients.

In another study of 1230 cytologically benign nodules, the overall malignancy risk was $2 \% 15$. The false negativity of FNAB increased up to $5.2 \%$ in nodules larger than $4 \mathrm{~cm}$ in this study. Our malignancy risk for category II was $4.3 \%$ which is slightly higher from $0-3 \%$ reported by TBSRTC10. The data regarding nodule size or incidental tumors were lacking in most patients in our study, thus we could not clarify the reason for false-negativity of our cases.

The diagnosis of TBRSTC III has been proposed to be under $7 \%$ of thyroid FNABs 10 . The interpretation of this category including "atypia of undetermined significance" and "follicular lesion of undetermined significance" widely vary among institutions and pathologists. In their multi-institutional study, Layfield et. all reported a wide range of the category III FNABs between 2.5\%-28.6\% among different pathologists ${ }^{16}$. Despite the Bethesda system has clarified the nomenclature and risk categorization, the reported malignancy risk of TBSRTC III is between $10-30 \%$ which is very conflictingfor a certain decision of surgery or follow-up. Recent ATA guideline recommends consideration of molecular testing for TBSRTC III $^{10}$. In our institution molecular testing has not been available yet. Repeat ultrasonographic evaluation is performed to identify high risk patients. In our series, $11 \%$ of the patients were in TBSRTC III category and $31.3 \%$ of those had malignancy which is compatible with the literature. One of the limitations of our study was lack of analysis of subgroups (cytologic atypia, architectural atypia, cytologic and architectural atypia, atypia with Hurtle cells) described by ATA for this category due to small number of patients. Apart from this, we did not perform a learning-curve analysis for TBSRTC reporting which has been suggested to influence the diagnostic accuracy ${ }^{9}$. Moreover, we used ATA guidelines instead of European Thyroid Association (ETA) which may be more compatible with Turkish population as one study by Isik et $\mathrm{al}^{17}$ from our country has shown. This study confirmed that ATA and ETA guidelines are jointly used in our country and following the national guidelines are strongly needed for standard management. The pathologic examinations interpreting indeterminate cytology were performed according to ATA guidelines in our institution, therefore our study was based on ATA recommendations.

The Bethesda system is currently the standard of care in reporting thyroid FNABs. The ATA guidelines and wide series suggest that institutional differences can be seen in implementation, even among different pathologists at the same institution. Thus, institutional and national validation of TBSRTC should be performed individually. Our results presented a single institution experience of a relatively novel diagnostic classification and confirmed the validity of TBSRTC recommendations in our institution. Multiinstitutional studies of larger numbers of patients are needed to adopt TBRSCT to nationwide practice setting.

Declaration of Conflicting Interests: The authors declare no conflict of interest.

Conflicts of interest: The authors have no conflict of interests to declare.

Financial Disclosure: The authors declared that this study has received no financial support. 


\section{REFERENCES}

1. Dean DS, Gharib H. Epidemiology of thyroid nodules. Best Pract Res Clin Endocrinol Metab. 2008; 22: 901-911. doi:10.1016/j.beem.2008.09.019.

2. Jemal A, Siegel R, Xu J, Ward E. Cancer Statistics, 2010. CA Cancer J Clin. 2010; 60: 277-300. doi:10.3322/caac.20073.

3. Yassa L, Cibas ES, Benson CB, et all. Long-term assessment of a multidisciplinary approach to thyroid nodule diagnostic evaluation. Cancer. 2007; 111: 508-516. doi:10.1002/cncr.23116.

4. Bongiovanni, A. Spitale, W. C. Faquin, L. Mazzucchelli, and Z. W. Baloch, "The Bethesda system for reporting thyroid cytopathology: A meta-analysis," Acta Cytologica. 2017; 61: 172.

5. Patrizia S, Diana RE, Tommaso B, et all. A meta-analytic review of the Bethesda System for Reporting Thyroid Cytopathology: Has the rate of malignancy in indeterminate lesions been underestimated? Cancer Cytopathol. 2015. doi:10.1002/cncy.21605.

6. D. Ozdemir, N. Bestepe, S. Faki, et all. "Comparison of thyroid fine needle aspiration biopsy results before and after implementation of Bethesda classification," Cytopathology, 2017 Oct; 28: 400-6.

7. P. S. Sullivan, S. L. Hirschowitz, P. C. Fung, and S. K. Apple, "The impact of atypia/follicular lesion of undetermined significance and repeat fine-needle aspiration: 5 years before and after implementation of the Bethesda System," Cancer Cytopathol., 2014 Dec; 122: 866-72.

8. E. Machała, J. Sopiński, I. Iavorska, and K. Kołomecki, "Correlation of Fine Needle Aspiration Cytology of Thyroid Gland with Histopathological Results," Polish J. Surg., vol. 90, no. 5, pp. 1-5, 2018.

9. H. Her-Juing Wu, C. Rose, and T. M. Elsheikh, "The Bethesda system for reporting thyroid cytopathology: An experience of 1,382 cases in a community practice setting with the implication for risk of neoplasm and risk of malignancy," Diagn. Cytopathol., 2012 May; 40: 399-403.
10. E. S. Cibas and S. Z. Ali, "The 2017 Bethesda System for Reporting Thyroid Cytopathology," J. Am. Soc. Cytopathol., vol. 6, no. 6, pp. 217-222, 2017.

11. R. L. Ferris, Z. Baloch, V. Bernet, et all. "American Thyroid Association Statement on Surgical Application of Molecular Profiling for Thyroid Nodules: Current Impact on Perioperative Decision Making," Thyroid, vol. 25, no. 7, pp. 760-768, 2015.

12. B. Haugen, E. K. Alexander, K. C. Bible, et all, "2015 American Thyroid Association Management Guidelines for Adult Patients with Thyroid Nodules and Differentiated Thyroid Cancer," The American Thyroid Association Guidelines Task Force on Thyroid Nodules and Differentiated Thyroid Cancer, 2016 Jan; 26: 1-133.

13. Her-Juing Wu H, Rose C, Elsheikh TM. The Bethesda system for reporting thyroid cytopathology: An experience of 1,382 cases in a community practice setting with the implication for risk of neoplasm and risk of malignancy. DiagnCytopathol. 2012. doi:10.1002/dc.21754.

14. Medina Chamorro FM, Calle JA, Stein JE, et all. Experience of the Implementation of Rapid On-Site Evaluation in Ultrasound-Guided Fine-Needle Aspiration Biopsy of Thyroid Nodules. CurrProblDiagnRadiol. 2018; 47: 220-4. doi:10.1067/j.cpradiol.2017.06.009.

15. Kim Y-Y, Han K, Kim E-K, et all. Validation of the 2015 American Thyroid Association Management Guidelines for Thyroid Nodules With Benign Cytologic Findings in the Era of the Bethesda System. Am J Roentgenol. 2018; 210: 629-34. doi:10.2214/AJR.17.18507.

16. Layfield LJ, Morton MJ, Cramer HM, Hirschowitz S. Implications of the proposed thyroid fine-needle aspiration category of "follicular lesion of undetermined significance": A five-year multiinstitutional analysis. DiagnCytopathol. 2009; 37: 710-4. doi:10.1002/dc.21093.

17. Isik A, Firat D, Yilmaz I et al. A survey of current approaches to thyroid nodules and thyroid operations. Int J Surg. 2018 Jun; 54(Pt A): 100-4. doi: 10.1016/j.ijsu.2018.04.037 